\title{
Environmental change in Danish marine waters during the Roman Warm Period inferred from mollusc data
}

\author{
Peter Rasmussen, Kaj Strand Petersen and David B. Ryves
}

Modern geological research into the late and postglacial history of the inner Danish waters (i.e. Kattegat, Bælthavet and Øresund, plus the adjoining fjords and estuaries) began at the turn of the last century. Since then most investigations have focused on the timing of the initial marine inundation of the area, the early to mid-Holocene changes in land-sea configuration and sea level changes during the mid-Holocene Littorina period. Research on the late Holocene marine environment has received less emphasis, undoubtedly due to problems in finding continuous marine sediment records, as sedimentation in large areas of the Danish waters seems to have been characterised by complex spatial and temporal patterns of deposition and non-deposition (e.g. Lykke-Andersen et al. 1993).

In an ongoing project we aim to explore the continuous development of Danish coastal environments over the last 9000 years using a variety of proxy data, including molluscs, diatoms, foraminifera, algal pigments, plant macrofossils and physical properties of sediments. The project spans both environmental and cultural history, and addresses the important links between them, as the nature of the coastal environment has exerted major influences on cultural and societal expression and activity from Mesolithic to mod-

Fig. 1. Map of Denmark showing the location of the two study sites Horsens Fjord and Tempelkrog in Isefjord and the present day sea surface salinities (psu; annual mean) in the Danish waters. The red dots indicate fjords and estuaries with Iron Age shell middens. (modified from Dahl et al. 2003). Bælthavet includes Storebælt and Lillebælt and the sea between the islands south of Fyn and Sjælland. ern times. This paper presents some of the first results from the project concerning environmental changes in the Roman Warm Period (c. 2000-1600 years B.P.) as shown by changes in molluscan faunas at two coring sites in Horsens Fjord and Tempelkrog in southern Isefjord (Fig. 1).

\section{Hydrography}

The present-day circulation pattern in the inner Danish waters is dominated by a two-layer estuarine flow, driven by outflow of low-salinity surface water from the Baltic Sea and

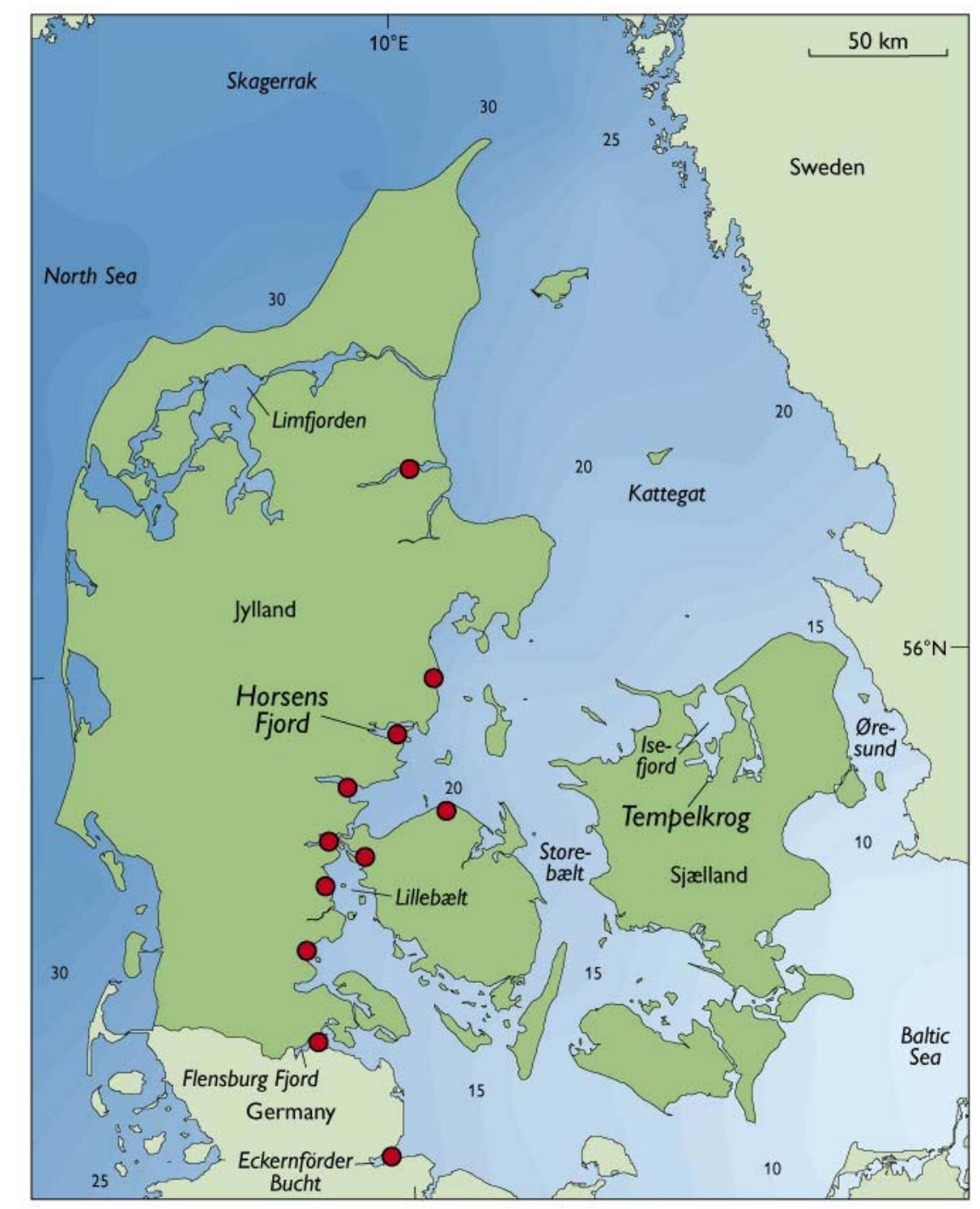



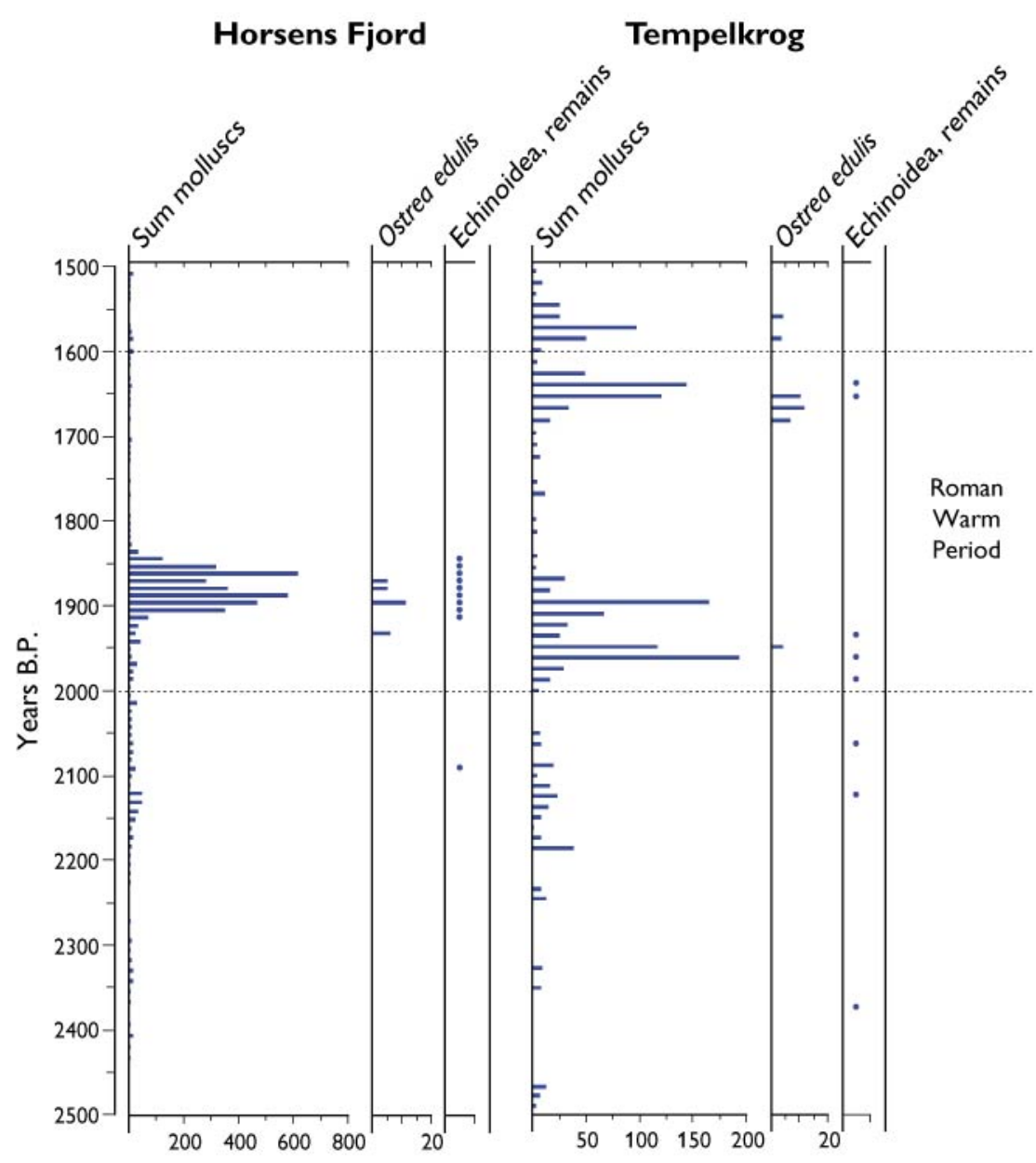

Fig. 2. Summary stratigraphic, macrofaunal data from two sediment cores from Horsens Fjord and Tempelkrog. Abundances of molluscs are expressed as specimens per $100 \mathrm{ml}$ of fresh sediment. Remains of echinoids are shown as present/not-present. The dotted lines delimit the Roman Warm Period. Note the change of $\mathrm{x}$-axis scale. inflow of high-salinity bottom water from the North Sea and Skagerrak. Due to high inflows of freshwater to the Baltic Sea from rivers there is a strong surface-salinity gradient from west to east: from $>30$ psu (practical salinity units, equivalent to ppt) in Skagerrak decreasing eastwards to $<5 \mathrm{psu}$ in the Baltic Sea (Fig. 1; Al-Hamdani et al. 2007 - this volume). There is also a strong salinity stratification (a halocline) within the water column, with a wedge of higher salinity, North Sea-derived water underlying less dense, less saline surface water.

\section{Material and methods}

Two sediment core lengths of $6 \mathrm{~m}$ and $13.5 \mathrm{~m}$ were extracted from respectively Horsens Fjord and Tempelkrog, both at a water depth of around $5 \mathrm{~m}$ and both consisting of homogeneous clay-gyttja. The two sediment records were Accelerator Mass Spectrometry (AMS) ${ }^{14} \mathrm{C}$-dated using terrestrial plant material, thus avoiding marine-derived material which suffers from uncertain reservoir and hard-water effects that can cause serious dating problems in Danish fjord and marine waters (Heier-Nielsen et al. 1995). The Horsens Fjord and Tempelkrog sediment cores were subsampled at intervals of
$1 \mathrm{~cm}$ and $2 \mathrm{~cm}$, respectively, which is equivalent to a resolution of 10-15 years in both records for the time period discussed in this paper. Molluscs were extracted from the cores by wet-sieving of known sediment volumes through a sieve with a mesh size of $0.1 \mathrm{~mm}$. Macrofaunal specimens were identified and counted and species numbers were calculated for $100 \mathrm{ml}$ of sediment (Fig. 2).

\section{Results and discussion}

\section{Molluscan faunas}

Based on analogies with their present-day ecological requirements in relation to salinity, temperature, depth and substrate, Quaternary molluscs are useful tools as indicators of environmental and climatic changes through time. Changes in surface salinity (and temperature) have often been linked with fluctuations in different marine populations, for example stocks of fish and molluscs, which tolerate only certain ranges of salinity and temperature. In the transitional area between the Skagerrak and the Baltic Sea, the salinity gradient seems to be the main limiting factor in the geographic distribution of mollusc species (Sorgenfrei 1958; Petersen 2004). 
Fig. 3. Section of an Iron Age shell midden at Horsens Fjord. The Iron Age middens are mainly composed of shells, charcoal and pot boilers (stones used in cooking) and are interpreted as specialised coastal sites used for gathering and processing of shellfish (Poulsen 1978). Mollusc analysis from North German middens suggests that they are seasonal sites used in the late summer or autumn (Anger 1973). Photograph courtesy of Karen Løkkegaard Poulsen.

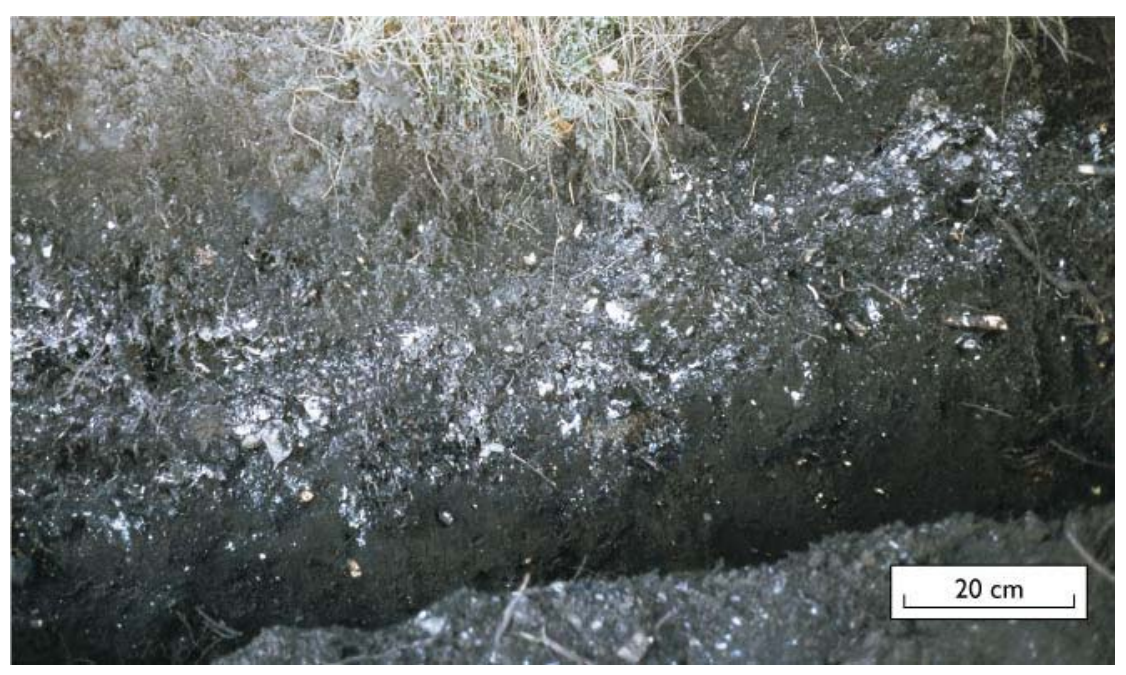

The summary stratigraphic, macrofauna data from Horsens Fjord and Tempelkrog during the period 2500 to 1500 years B.P. are shown in Fig. 2. At both sites there is a distinct increase in mollusc abundance at the beginning of the Roman Warm Period between c. 2000 and 1850 years B.P. and at Tempelkrog again at the end of the Roman Warm Period. At Horsens, this increase is mainly due to Mytilus edulis (blue mussel), Rissoa albella, $R$. albella var. sarci, Bittium reticulatum, Cerastoderma edule (common cockle) and Mysella bidentata, and at Tempelkrog, Hydrobia ulvae, $H$. ventrosa, $H$. neglecta and Rissoa albella. At both sites, this increase in mollusc abundance is accompanied by the appearance of Ostrea edulis (European flat oyster) and a more steady presence of remains of echinoids (sea urchins), both indicating more saline conditions than in the period before or after (Fig. 2). Ostrea edulis needs at least 25 psu in order to reproduce (Jensen \& Spärck 1934) and is not present in the inner Danish waters today, except for the western part of Limfjorden which is connected to the North Sea. Furthermore, the reproductive success of Ostrea edulis is very sensitive to temperature with optimal conditions around $20-22^{\circ} \mathrm{C}$ (Spärck 1924). Echinoids are generally stenohaline and therefore disappear when the water becomes brackish (c. 10 psu). In addition, other mollusc species, which also indicate an increase in salinity to $>25$ psu, appear at Horsens Fjord, although with low abundance. These include Parvicardium scabrum, Abra nitida, Rissoa violacea, Gari fervensis, Velutina velutina, Odostomia umbilicaris and Abra prismatica (Sorgenfrei 1958).

The two study sites are located $120 \mathrm{~km}$ apart and the similar pattern in macrofaunal assemblages, with an increase in mollusc abundance and the appearance of a suite of almost fully marine taxa at various times during the Roman Warm Period, thus testifies to a widespread change to more saline and productive conditions across the inner Danish waters.
The fairly regular presence of Ostrea edulis (see below) may also suggest an increase in sea surface temperature during this period. The reason for two (or three) 'episodes' with changes in faunal compositon at Tempelkrog and only one at Horsens Fjord is unclear but could be a result of spatial or temporal differences in substrate, local current conditions or postmortem (taphonomic) processes.

\section{Sea and society}

Inferences of higher salinity and productivity during the Roman Warm Period from the palaeoenvironmental data are also supported by an independent line of evidence from the archaeological record. Large shell middens dated to the centuries around 2000 years B.P., and predominantely composed of Mytilus edulis, Cerastoderma edule, Littorina littorea (common periwinkle) and to a lesser extent Ostrea edulis, are recorded along several Danish and North German fjords (Figs 1, 3; Anger 1973; Harck 1973; Poulsen 1978; Petersen 1985). The synchroneity between the inferred changes in the marine environment and the appearance of these Iron Age shell middens strongly suggest a causal connection between the two, implying that people responded to the increased productivity in the marine environment by a comprehensive and targeted gathering and processing of shellfish.

\section{Outlook}

The evidence of salinity increase in the inner Danish waters during the Roman Warm Period only seems to be explicable by the more frequent inflow of high-salinity North Sea water, which travelled through the Danish straits and further east into the Baltic Sea. This scenario is supported by the presence of Ostrea edulis in Iron Age shell middens as far into the Baltic as the head of Flensburg Fjord and Eckernförder Bucht 
(North Germany; Anger 1973; Harck 1973); this is only possible through a combination of a more frequent input of high-salinity water and a higher rate of water exchange than today. The increased inflow of North Sea water seems to have penetrated as far as the central Baltic Sea where diatom and isotopic data also suggest a salinity rise during the Roman Warm Period (Emeis et al. 2003). Diatom-based sea-surface salinity reconstructions from southern Skagerrak also indicate higher salinity during the period (Hebbeln et al. 2006), in good agreement with our results from the Danish waters and evidence from the Gotland Basin (Emeis et al. 2003).

\section{Future work}

Work is ongoing to analyse the other proxy records from the two sites over the last 9000 years to provide additional independent environmental information and to test the inferences made from the subfossil mollusc data. For instance, a model to relate fossil diatom assemblage composition to past surface-water salinity is being developed using a large range of contemporary samples from the western Baltic Sea, Limfjorden and coastal brackish lakes and fjords (the MOLTEN project: http://craticula.ncl.ac.uk/Molten/jsp/; Ryves et al. 2004). Coastal sediments contain important natural archives of past environmental changes and palaeoecological techniques can provide a powerful means of revealing the natural variability of the marine environment and the links between environmental and socio-cultural changes over time. Furthermore, this approach can establish the nature of environmental conditions in nearshore marine areas prior to the impact of modern society on coastal regions. It is especially important to establish ecological baseline conditions before realistic goals for environmental management of coasts can be set.

\section{Acknowledgements}

The ongoing research project Denmark's coastal environment over the last 9000 years: linking cultural and hydrographic change is co-financed by the Danish Research Council for the Humanities (FKK) and the Danish Natural Science Research Council (FNU), whose support is gratefully acknowledged. Additional funding for the project has been provided by Loughborough University, UK. Karen Løkkegaard Poulsen is thanked for information about Iron Age shell middens.

\section{References}

Al-Hamdani, Z.K., Reker, J., Leth, J.O., Reijonen, A., Kotilainen, A.T. \& Dinesen, G.E. 2007: Development of marine landscape maps for the Baltic Sea and the Kattegat using geophysical and hydrographical parameters. Geological Survey of Denmark and Greenland Bulletin 13, 61-64.

Anger, K. 1973: Untersuchungen an eisenzeitlichen Muschelhaufen an der Flensburger Förde. Offa 30, 55-59

Dahl, K., Lundsteen, S. \& Helmig, S.A. 2003: Stenrev - havets oaser, 104 pp. Copenhagen: Gads Forlag.

Emeis, K.-C., Struck, U., Blanz, T., Kohly, A. \& Voss, M. 2003: Salinity changes in the Baltic Sea (NW Europe) over the last 10000 years. The Holocene 13, 411-421.

Harck, O. 1973: Eisenzeitliche Muschelhaufen an der schleswigschen Ost- und Westküste. Offa 30, 40-54.

Hebbeln, D., Knudsen, K.-L., Gyllencreutz, R., Kristensen, P., KlitgaardKristensen, D., Backman, J., Scheurle, C., Jiang, H., Gil, I., Smelror, M., Jones, P.D. \& Sejrup, H.-P. 2006: Late Holocene coastal hydrographic and climate changes in the eastern North Sea. The Holocene $\mathbf{1 6}$, 987-1001.

Heier-Nielsen, S., Heinemeier, J., Nielsen, H.L. \& Rud, N. 1995: Recent reservoir ages for Danish fjords and marine waters. Radiocarbon 37, 875-882.

Jensen, A.S. \& Spärck, R. 1934: Bløddyr II. Saltvandsmuslinger. Danmarks Fauna 40, 208 pp.

Lykke-Andersen, H., Knudsen, K.L. \& Christiansen, C. 1993: The Quaternary of the Kattegat area, Scandinavia: a review. Boreas 22, 269-281.

Petersen, K.S. 1985: Det sydfynske arkipelag. Dets geologiske udvikling med særlig hensyntagen til havniveauændringer og den marine molluskfauna. In: Skaarup, J. (ed.): Yngre Stenalder på øerne syd for Fyn, 15-27. Rudkøbing: Langelands Museum.

Petersen, K.S. 2004: Late Quaternary environmental changes recorded in the Danish marine molluscan faunas. Geological Survey of Denmark and Greenland Bulletin 3, 268 pp.

Poulsen, K.L. 1978: Eisenzeitliche Muschelhaufen in Dänemark. Offa 35 , 64-85.

Ryves, D.B., Clarke, A.L., Appleby, P.G., Amsinck, S.L., Jeppesen, E., Landkildehus, F. \& Anderson, N.J. 2004: Reconstructing the salinity and environment of the Limfjord and Vejlerne nature reserve, Denmark, using a diatom model for brackish lakes and fjords. Canadian Journal of Fisheries and Aquatic Sciences 61, 1988-2006.

Sorgenfrei, T. 1958: Molluscan assemblages from the marine middle Miocene of South Jutland and their environments. Danmarks Geologiske Undersøgelse II. Række 29, 356-503.

Spärck, R. 1924: Undersøgelser over Østersens (Ostrea edulis) Biologi Limfjorden, særlig med Henblik paa Temperaturens Indflydelse paa Kønsskiftet, 82 pp. København: Centraltrykkeriet.

\section{Authors' addresses}

P.R. \& K.S.P., Geological Survey of Denmark and Greenland, Øster Voldgade 10, DK-1350 Copenhagen K, Denmark. E-mail: per@geus.dk D.B.R., Department of Geography, Loughborough University, Loughborough, Leicestershire, LE11 $3 T U$, UK. 